\title{
Analysis of Global Perspectives and Principal Policies on Their Influence on the Professional Commitment of Public Vocational Teachers in Padangsidimpuan
}

\author{
Hanafi $^{1, *}$, Nurhizrah Gistituati ${ }^{1}$, Rusdinal $^{1}$, Hasdi Aimon ${ }^{1}$ \\ ${ }^{1}$ Universitas Negeri Padang \\ *Corresponding author. hanafi2568@gmail.com
}

\begin{abstract}
This study aims to build a hypothetical model consisting of a structural model and a measurement model in the form of a path diagram based on the theoretical justification of the teacher's global perspective variables, principal policies, and professional commitment. The population in this study was all certified teachers of State Vocational Schools in Padangsidimpuan, namely 338 people. Sampling was carried out proportionally with a sample of 200 people. This research instrument is a questionnaire. The questionnaire was used to collect data on the global perspective of teachers, principal policies, and professional commitment. The data obtained were analyzed using the SEM method. The research results show that: there is a positive influence from the global perspective of teachers on professional commitment. The results of this study can confirm the conclusions of previous research results
\end{abstract}

\section{Keywords: global perspective, principal policy, professional commitment}

\section{INTRODUCTION}

Unpreparedness for the effect of globalization can be overcome by mastering science and technology, this can be preceded by awareness and insight into the global perspective of all generations of the nation. With an increasingly global perspective, we can understand the world and everything in it, thus raising awareness that a world that is so complex and wide can be narrow and simple. It is very important to examine more deeply the importance of having a global perspective such as global awareness and insight, increasing competitiveness in globalization, and no less important how to increase the awareness of students about globalization, especially vocational school students who are faced with the business world and the industrial world who are faced with global challenges.

Vocational High School as a graduate-oriented school who is ready to work, must be able to produce superior human resources who have both hard skills and soft skills needed by the world of work today. The crucial problem at this time is that vocational education currently still tends to be oriented towards hard skills, of course, it is no longer relevant to the demands of the business world, especially in the current global era. These student problems are so complex and if these problems are left unchecked, then vocational school graduates will not be accepted into jobs which will ultimately increase the unemployment rate.

Based on data in the field, it shows that the feasibility of teachers in teaching is still in doubt. also shows that there is still a low number of teachers who meet the standard qualifications in vocational education. Several studies have shown that professional teachers are an important indicator of a quality school. Professional teachers will greatly assist the process of achieving the school's vision and mission. Iim [1] argued that based on the results of studies in developing countries, teachers contributed to student achievement (36\%), then management $(23 \%)$, study time $(22 \%)$, and physical facilities (19\%).

Another thing that requires improving teacher competence is because most teachers are still not professional, this can be seen from the results of the Teacher Competency Test in 2016 [2], where teachers of State Vocational High Schools throughout Padangsidimpuan took the Teacher Competency Test which was attended by 258 only $46 \%$ of participants achieved the criteria for sufficient value. The condition of the failure of the UKG needs to be found for the cause and the best solution, especially for education policymakers. The results of the UKG that have been implemented that for the field of teacher professionalism competence can be seen in the following histogram:

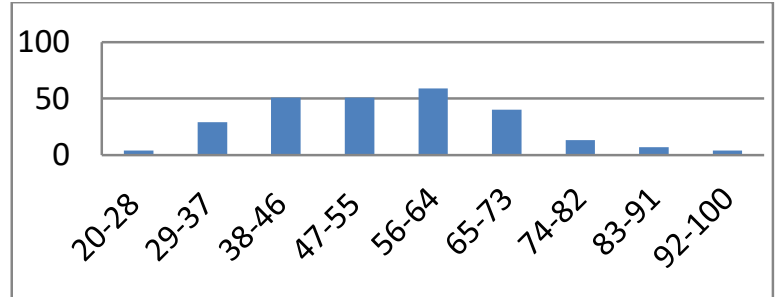

Figure 1.Graph of the Competency Test Results for 
Vocational School Teachers in Padangsidimpuan 2016

From the histogram above, it can be seen that the results of UKG on the professional competence of teachers of State Vocational High Schools in Padangsidimpuan are still far from ideal, where $60 \%$ of teachers in professional competence are still below the graduation criteria. The Regional Government of Padangsidimpuan has made efforts to improve teacher professionalism, including increasing the qualifications and requirements for higher education levels, especially State Vocational High Schools in Padangsidimpuan, where every teacher teaching at State Vocational High Schools is required to have a minimum qualification of a bachelor's degree and all teachers are strived to become certified teachers. Besides that, the Padangsidimpuan education office is trying to activate the subject teacher discussion but in fact, the results of the Padangsidimpuan Government program have not been satisfactory.

This research is important because the results of this research can be used as a basis for policymaking in fostering professionalism and global insight of teachers through professional commitment. Among the efforts to increase professional commitment can be done by increasing the global perspective of teachers. This research is expected to be able to answer the problem of the low quality of teachers and this will be an alternative answer to the demands for continuous improvement of teacher professionalism and professional commitment which must be carried out according to the development of science and the demands of globalization.

\subsection{Professional Commitment}

The teacher is a strategic position for the empowerment and learning of a nation that cannot be replaced by any element. The more significant the existence of teachers in carrying out their roles and duties, the more guaranteed the creation of reliability and the readiness of students. For that, we need teacher commitment that the portrait of teachers in the present and the progress of the dynamics of life is very dependent on the image of the teacher in the midst of society. A teacher needs to be committed to the importance of the ability to understand himself and his duties, to emit inner strength (inner strength), and to be responsive to change.

Teachers who are committed to the task at least from within themselves emanate several attitudes [3], namely; 1) The task as a teacher is a reflection of the inner attitude. 2) Carrying out duties as a teacher should be a calling from the soul that is born of sincerity to carry out the task seriously without being forced and forced. 3) Ready anywhere. Commitment is a psychological state that identifies an individual openness associated with a desire to get involved. With the high commitment of teachers in their involvement in school, it can be ascertained that they can affect student achievement.

Many factors influence the professional commitment of teachers in the learning process in schools. Strum in Etta [4] suggests that 5 factors influence work commitment, namely: a. culture of openness, b job satisfaction, c. personal opportunity, d. organizational direction, and e. work awards by needs. Then according to Louis in Ahmad and Razak [5] it explains 4 types of teacher commitment, namely; a) Commitment to the school as a social unit, b) Commitment to school academic activities, c) Commitment to students as unique individuals, and d) Commitment to creating quality teaching.

\subsection{Global Perspectives}

The global perspective is a view that arises from the awareness that in this life everything is always related to global issues. It is no longer possible for people to isolate themselves from global influences. As a result of technological developments, all aspects of human life are increasingly transparent and global, as well as education. A global perspective is defined as a perspective and way of thinking about a problem, event, or activity of global interest, namely from the side of the world or international interests. In this case, we are reminded that what we do will affect the world globally. Hanvey [6] in his very famous book "An Attainable Global Perspective" mentions 5 dimensions from a global perspective as follows. A) Perspective consciousness b) State of planet awareness c) State of planet awareness d). Systemic awareness e) Options for participation.

A global perspective is very important for educators, given that we are entering an era of globalization and openness. Without understanding this world, maybe we are lost by the swift currents of globalization. For us to be able to take advantage of this world for human welfare, we must understand the world. Thus, our perspective which may have been narrow so far must change into a broad and global perspective. In connection with the global perspective an SMK teacher must play a role; a). Providing knowledge to students about the importance of global knowledge in understanding world problems, b) Increasing awareness and insight of students as a basis for taking action that has a global impact, and c) Providing examples and examples in daily activities, which influences global problems.

\subsection{Principal Policy}

The principal's policy is an important indicator for the principal in focusing his actions on setting school goals, defining school goals, providing the necessary resources in the learning process. Its actions are to supervise and evaluate teachers, coordinate staff development programs, and create peer-to-peer relationships with and between teachers. Thus, the principal is in the front position amidst his school teachers, employees, and students. Educational policy or school policy will run well if the policy has certain aspects and feasibility.

The indicators of principal policies in this paper are a) Policies in giving awards to teachers, b) Policies on improving teacher professionalism, and c) Policy on teacher performance appraisal. For more details, the following describes the three schools above. To create teacher welfare, as well as foster high work motivation. The teacher reward system must be built as a culmination 
of the unity of various interrelated variables [7], namely: a. work performance, b. education level, c. experience/years of work, d. workload, e. creativity, f. location or work environment, g. rank. Giving awards for the position of teachers as professionals functions to improve teacher performance and the role of teachers as agents of learning to improve the quality of national education

This research is important because the results of this research can be used as a basis for policymaking in fostering professionalism and global insight of teachers through professional commitment. Among the efforts to increase professional commitment can be done by increasing the global perspective of teachers. This research is expected to be able to answer the problem of low teacher quality and this will be an alternative answer to the demands of increasing teacher professionalism and continuous professional commitment which must be carried out by the development of science and the demands of globalization.

\section{METHODOLOGY}

\subsection{Type and intensity of research}

Under the problems and research objectives to be achieved, this study uses quantitative methods with the type of ex post facto research. This research was conducted in State Vocational High Schools in Padangsidimpuan. The population in this study were all civil servant teachers in State Vocational High Schools in Padangsidimpuan as many as 338 teachers. In general, the sample size for the structural equation model is at least 200 observations. The determination of the sample size in this study refers to the opinion of Joreskog and Sorbom where the number of samples with 5 variables is a minimum of 200 respondents. The sample-set in this study is the State Civil Service teacher who has taken the teacher competency test conducted by the Padangsidimpuan Education Office.

The instrument used to collect data in this study was a questionnaire. The questionnaire was distributed to respondents, namely teachers at State Vocational High Schools in Padangsidimpuan who had been assigned as research samples to answer the questionnaire provided by the researcher. Furthermore, the respondent provides an assessment or determines the opinion freely to choose one of the five available answer options according to what they experienced, on the questionnaire distributed by the researcher.

\subsection{Data Analysis Techniques}

Data analysis in this study uses descriptive analysis, assumption testing, and statistical analysis using Structural Equation Modeling (SEM) analysis based on several reasons as follows: first, this study wants to test the structural model, examine the effect of exogenous variables, namely the global perspective of teachers and head policies. schools towards endogenous variables, namely professional commitment. In detail, testing is carried out on the suitability of the model through the goodness of fit with certain criteria.
All data obtained from respondents who are used as research samples through questionnaires distributed will be analyzed using Structural Equation Modeling (SEM) based on the AMOS 22 and SPSS 23 programs. The AMOS program shows structural problem measurements, and is used to test hypothesized models. . This is due to the ability to: estimate known coefficients from structural linear equations, accommodate models that are latent variables, accommodate measurement errors in the dependent and independent variables, accommodate simultaneous reciprocal warnings and interdependence.

The steps to form a structural equation model in this study include the use of several developments, validity, and reliability of research instruments, evaluation of the Goodness of Fit criteria, testing the SEM model assumptions, and testing the structural models. According to Hair, [8] is as follows:

\section{a. Theory-Based Model Development}

The first step in modeling is the development of a model that has a strong theoretical justification. Structural Equation Models (structural equation models) are based on causal relationships, where changes that occur in a variable are assumed to result in changes in other variables. The model to be observed is following what is reflected in the framework of thought, which is related to the influence of the global perspective of teachers and principal policies on professional commitment. A global perspective and principal policies have a positive impact on the professional commitment of teachers themselves

\section{b. Path diagram arrangement}

The theoretical model that was built in the first step will be depicted in the path diagram. The path diagram will make it easier to see the causal relationships between the independent variable and the dependent variable. To see the causality relationship, several models were made and then tested using SEM to get the most appropriate model, with Goodness of Fit criteria. Based on the theory, a structural model is made, then the independent variables and the dependent variable are determined, then the arrow direction is made according to the direction of causality.

Based on the theoretical basis, a path diagram for SEM (structural model) is made as follows:

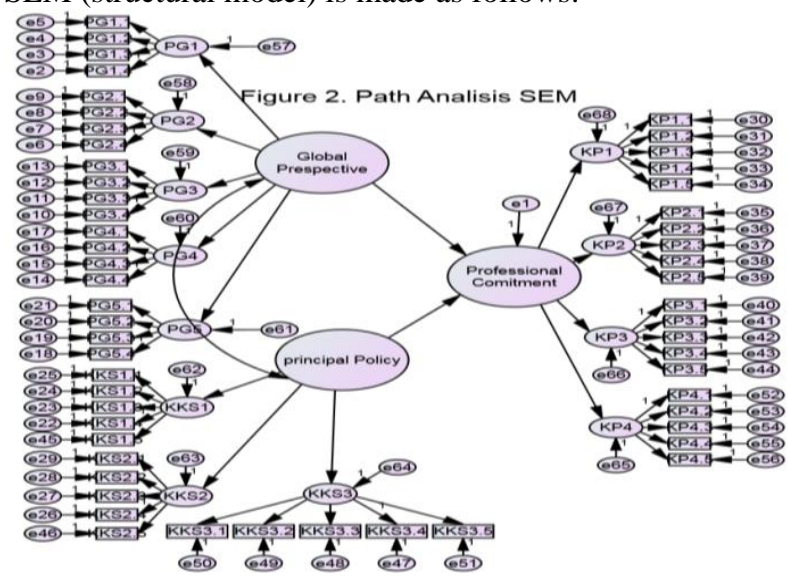

Figure 2. Path Analysis SEM 
c. Convert path diagrams into structural equations and measurement models

In measuring the research variables, it is developed from indicators as observable variables (manifest variables): (in SEM terminology, unobservable variables are described in the form of an ellipse, and observable variables or manifest variables are depicted in squares). Latent variables are in the form of indicators using Confirmatory Factor Analysis techniques. In SEM, measuring indicators to variables is called a measurement model. Convert flowcharts into structural equations and measurement models.

So the structural equation is:

$\mathrm{Y} 1=\beta+\gamma 1 \mathrm{X} 1+\gamma 2 \mathrm{X} 2+\gamma 3 \mathrm{X} 3+\zeta 1$

Information:

$\gamma($ Gama $)=$ coefficient of influence of exogenous variables on endogenous variables

$\beta$ (Beta) $=$ coefficient of influence of endogenous variables on other endogenous variables.

$\zeta($ Zeta $)=$ model error

\section{d. Selecting the Input Matrix Type and Model Estimates}

In testing, the input matrix used in this study is the Hair covariance matrix [9], that by using a covariance matrix not only analyzes the pattern of causal relationships between latent variables, but it can also test a hypothetical model, the model obtained can explain the phenomenon being studied.

\section{e. Assessing Structural Model Identification}

In AMOS operations, identification problems are handled directly by the program. If estimates cannot be made, the program will provide a message regarding possible reasons why this program cannot make estimates, so that researchers can plan possible corrective actions. How to see whether there is an identification problem or not is to look at the estimation results which include the following: a. There is a large standard error value for one or more coefficients, $\mathrm{b}$. The program is unable to produce the information matrix that should be presented, c. Impossible estimation values such as negative error variance, and $\mathrm{d}$. There is a high correlation value (>0.90) between the estimation coefficients.

\section{f. Evaluation of Goodness of Fit Criteria}

This stage is carried out by testing the suitability of the model through a review of various goodness of fit criteria. In empirical research, a researcher is not required to meet all the goodness of fit criteria, but it depends on the judgment of the researcher. According to Haryono [10], the use of 4-5 criteria for the goodness of fit is considered sufficient to assess the feasibility of a model provided that each criterion of the goodness of fit is 1). Absolute fit indices, 2). Incremental fit indices and, 3) Parsimony fit indices represented. Absolute fit indices (a measure of absolute fit) according to Wijanto [11] determine the degree of prediction of the overall model (structure and measurement models) against the corrective matrix and ovarian $\mathrm{k}$. These measures include Chi-square (X2), CMIN / DF, NCP, GFI, RMR, RMSEA, and ECVI.
Incremental fit indices are a comparison of the proposed model (baseline model) with the basic model (null model). According to Muller [12], this incremental fit measure contains a measure that represents the perspective of comparative fit to the base model. The closer to the model structure, the better the fit. These measures include GFI, AGFI, TLI, NFI, RFI, IFI, and CFI. Parsimony fit indices according to Wijanto in Haryono [13] the parsimony fit measure relates the GOF model to the estimated number of parameters, which is needed to achieve a match at that level. The measure of parsimony suitability is expected to obtain the highest degree of fit for the degree of freedom. These measures include; PNFI, PGFI.AIC, CAIC.

Table 1. Goodness of Fit criteria

\begin{tabular}{|c|c|c|}
\hline Jenis Ukuran & Ukuran & Kategori \\
\hline \multirow{4}{*}{ Absolut Fit Measure } & Chi-Square & $\geq 0,05$ \\
\hline & $\begin{array}{l}\text { Goodness Of Fit Index } \\
\text { (GFI) }\end{array}$ & $>0,90$ \\
\hline & $\begin{array}{l}\text { Root Mean Square Error Of } \\
\text { Approximation (RMSEA) }\end{array}$ & $<0,08$ \\
\hline & $\begin{array}{l}\text { Root Mean Square Residual } \\
\text { (RMR) }\end{array}$ & $<0,05$ \\
\hline \multirow{5}{*}{ Incremental Fü Measure } & $\begin{array}{l}\text { Adjusted Goodness Of Fit } \\
\text { Index (AGFI) }\end{array}$ & $>0,90$ \\
\hline & Tucker Lewis Index (TLI) & $>0,90$ \\
\hline & Comparative Fit Index (CFI) & $>0,90$ \\
\hline & Incremental Fit Index (IFI) & $>0,90$ \\
\hline & Relative Fit Index (RFI) & $\geq 0,95$ \\
\hline \multirow{4}{*}{ Parsimonious Fit Measure } & $\begin{array}{l}\text { Parsimonious Normed Fit } \\
\text { Index (PNFI) }\end{array}$ & $\begin{array}{l}\text { Semakin Besar, } \\
\text { Semakin Baik }\end{array}$ \\
\hline & $\begin{array}{l}\text { Parsimonious Googness Of } \\
\text { Fit Index (PGFI) }\end{array}$ & $\begin{array}{l}\text { Semakin Besar, } \\
\text { Semakin Baik }\end{array}$ \\
\hline & $\begin{array}{l}\text { Akaike Information } \\
\text { Criterion (AIC) }\end{array}$ & $\begin{array}{l}\text { Positif dan } \\
\text { Lebih Kecil }\end{array}$ \\
\hline & $\begin{array}{l}\text { Consistent Akaike } \\
\text { Information Criterion } \\
\text { (CAIC) }\end{array}$ & $\begin{array}{l}\text { Positif dan } \\
\text { Lebih Kecil }\end{array}$ \\
\hline
\end{tabular}

Source: Haryono, [14]

\section{RESULTS}

A structural model is proposed to test the research hypothesis. The structural model describes the relationship of 3 latent variables, namely: the global perspective of teacher policies, principals, and professional commitment. Teacher global perspective latent variables by 5 manifest variables, namely PG1, PG2, PG3, PG4, and PG5. After the goodness of fit (GOF) test was carried out, the manifest variables that were feasible to measure the teacher's Global Perspective alternative variable were the PG1, PG3, and PG4 manifest variables.

The principal's policy variable is represented by 3 manifest variables, namely KKS1, KKS2, and KKS3. After the goodness of fit (GOF) test is carried out, the manifest variables that are feasible to measure the latent variables of school principal policies are the manifest variables KKS2 and KKS3. The latent variable for professional commitment is represented by four manifest variables KP1, KP2, K3, and KP4. After the goodness of fit (GOF) test is carried out, the manifest variables that are feasible to measure the latent variables of professional 
commitment are the manifest variables $\mathrm{KP} 1, \mathrm{KP} 2$, and KP3.

The model can be described as shown below:

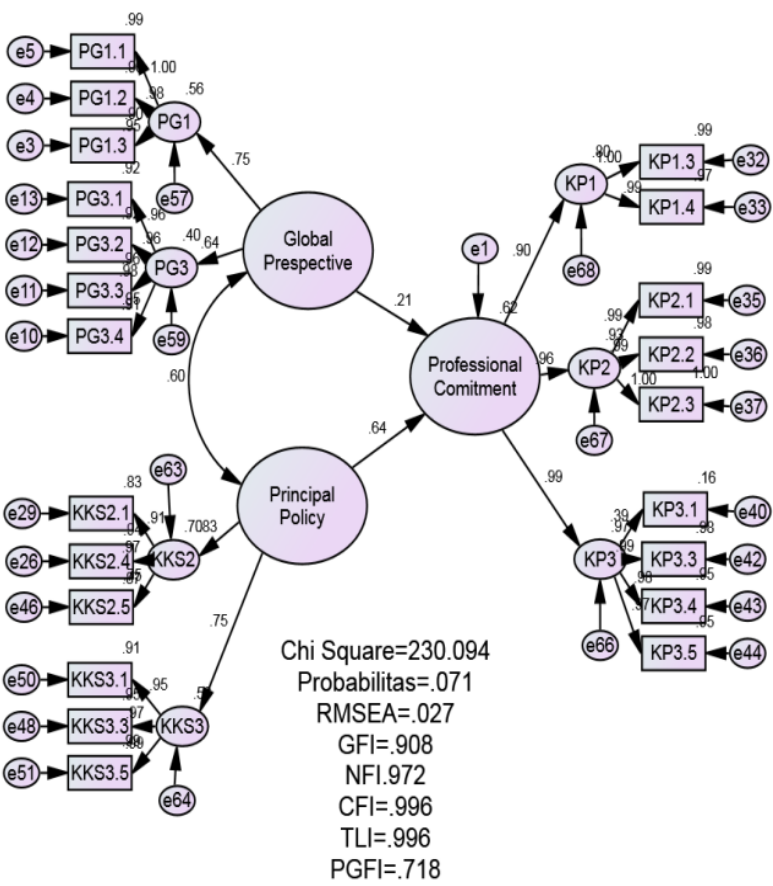

Figure 3. Structural Model that Describes the Relationship Between Variables to Test the Research Hypothesis

Evaluation of the criteria for the goodness of fit for the global perspective variable of teachers, principal policies, and professional commitment teacher competencies can be seen in Table 2 below::

Table 2.

Evaluation of Goodness of Fit Criteria on Modified Structural Equation Modeling

\begin{tabular}{cccl}
\hline $\begin{array}{c}\text { Goodness of } \\
\text { Fit Index }\end{array}$ & $\begin{array}{c}\text { Cut-off } \\
\text { Value }\end{array}$ & est results & Criteria \\
\hline $\mathrm{X}^{2}$ - Chi- & $<171.907$ & 230,094 & Fit \\
Probabilitas & $\geq 0,05$ & 0,071 & Fit \\
RMSEA & $\leq 0,08$ & 0,027 & Fit \\
GFI & $\geq 0,90$ & 0,908 & Fit \\
NFI & $\geq 0,90$ & 0,972 & Fit \\
CFI & $\geq 0,90$ & 0,996 & Fit \\
TLI & $\geq 0,90$ & 0,995 & Fit \\
PGFI & $\geq 0,90$ & 0,718 & margin fit \\
\hline
\end{tabular}

From table 2 above, it can be seen that the results of the Sign test. Probability has a value of 0.071 or greater than 0.05 so that it is in the fit category. Of the eight criteria for the equation model test, 7 categories are fit, namely; chi-square, probability, RMSEA, GFI, NFI, CFI, TLI, and PGFI are fit. Following Hair's opinion in Haryono [15] the use of 4-5 criteria for the goodness of fit is considered sufficient to assess the feasibility of a model provided that each criterion of the goodness of fit is 1). Absolute fit indices, 2). Incremental fit indices and, 3) Parsimony fit indices are represented.

This means that the data from the structural equation model for the global perspective variable of teachers, and the principal's policies on professional commitment are following the model so that the analysis can be continued. Meanwhile, the output of the Regression Weight from AMOS 22 for the Structural Model can be seen in the following table

Table 3.

Estimasi Regression Weights dari Model Struktural

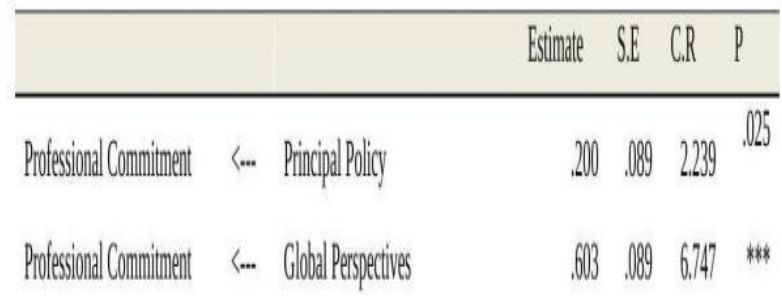

From Table 2, it can be seen that the overall significance level of the hypothesized relationship between latent constructs is significant, which is indicated by a probability value $(\mathrm{P})$ that is smaller than 0.05 . Hypothesis 1 (H1) which states that "There is a positive influence from the global perspective of teachers on professional commitment at State Vocational High Schools in Padangsidimpuan" cannot be rejected significantly, at the 0.05 level, with a critical value (critical ratio) of 2.339. In the estimation column, it can also be explained that when the global perspective increases by 1 level, professional commitment increases by 0.200 . In conclusion, H1 is accepted.

Hypothesis $2(\mathrm{H} 2)$ which states that "There is a positive effect of the principal's policy on professional commitment at State Vocational High Schools in Padangsidimpuan" cannot be rejected significantly, at the 0.05 level, with a critical value (critical ratio) of 6.747 . In the estimation column, it can also be explained that when the principal's policy increases by 1 level, professional commitment increases 0.603 . In conclusion, $\mathrm{H} 2$ is accepted

This study found that there is a significant and irresistible positive influence on the global perspective of teachers and principal policies on professional commitment. These findings can confirm the findings of research conducted by:

Bassey Enya and Josephine Dasel's [15] research entitled Teacher Education And Global Standards For Effective Teaching-Learning Process In Public Secondary Schools 
In Calabar Municipality. From the results of the data analyzed from the hypothesis, it is clear that global standard education has a positive relationship with the effectiveness of learning. Teachers who come from educational institutions that have a global perspective will help countries-Nigeria to achieve an educational standard for an effective learning process and have a global perspective. This situation makes students understand what has been taught to them.

Another important finding in the research of Leah [16] entitled Global Perspective perspective in curricula and deep approaches to learning: Examining faculty practices for engagement. This study produces a significant and positive relationship between Global Perspectives with Reflective \& Integrative learning and Higher-Order Learning. This research also produces a global curriculum that contains a high level of reflection, is generated from various perspectives, and links to global issues. The global perspective reflects a global and holistic view of student learning and development. For this reason, the role of the school environment is very important in encouraging holistic student development. It measures how a student thinks, views himself or herself as a person with cultural heritage, and relates to other people from other cultures, backgrounds, and values.

In conclusion, the findings of this study indicate the need for learning that enhances students' global insight. A global perspective approach to cross-cultural learning is something that needs to be developed, where the global competence of students will greatly influence their future career development.

\section{CONCLUSION}

This study concludes that the global perspective of teachers and school principal policies have a positive influence on the professional commitment of teachers at SMK Negeri Kota Padangsidimpuan.

\section{REFERENCES}

[1] Iim Wasliman. Elevating Teacher's Image Through Competency Mastery 2006 Mimbar Pendidikan http://jurnal.upi.edu/mimbar-pend

Pendidikan/edition/71/mimbar-no-4-2006

[2] Padangsidimpuan Education Office Teacher Competency Test (UKG) Results in 2016

[3] Ahmad and Rajak. 2007. Teacher's Commitment, Jakarta: Erlangga.

[4] Etta Mamang Sangadji, Sopiah. 2018. Strategic Human Resource Management. Yogyakarta: ANDI

[5] Ahmad and Rajak. 2007. Teacher's Commitment, Jakarta: Erlangga

[6] Hanvey, Robert, G.1976.AnAttainableGlobal Perspective.ttp: //ebookbrowse.com/hanvey-an-attainableglobal-perspective-pdf-d379707707
[7] Burhanudin, Analysis of Educational Management and Leadership Administration. Earth literacy, Jakarta, 2007

[8] Hair. Joseph F. Multivariate Data Analysis. 2006 Faculty Analysis https://digitalcommons.kennesaw. edu/facpubs/2925/

[9] Hair J. F., Hult, G. T.M., Ringle, C.M., \& Sarstedt, M. 2014. A primer on partial least squares structural equation modeling (PLS-SEM) (1 ed.). Thousand Oaks, CA: Sage

[10] Haryono, Siswono. SEM Method for Management Research, Jakarta: Luxima Metro Media 2017

[11] Wjanto, Setyo Hari, 2008. Structural Equation Modeling with Lisrel 8.8 Concepts and Tutorials, Graha Ilmu

[12] Muller Structural Determinants of Job Satisfaction and Organizational Commitment in Turnover Models. Human Resource Management Review Volume 9, Issue 4, Winter 1999, Pages 479-493

[13] Haryono, Siswono. SEM Method for Management Research, Jakarta: Luxima Metro Media 2017

[14] Haryono, Siswono. SEM Method for Management Research, Jakarta: Luxima Metro Media 2017. p. 77

[15] Bassey Enya and Josephine Dasel. Teacher Education And Global Standard For Effective Teaching Learning Process In Public Secondary Schools In Calabar Municipality, Cross River State, Nigeria 2014. C: /Users/windows\%207/Downloads/2982-Article\%20Text8796-1-10-20140331.pdf

[16] Leah K. Peck Yi-Chen Chiang Allison BrckaLorenz. Global perspectives in curricula and deep approaches to learning: Examining faculty practices for engagement http://cpr.indiana.edu/uploads/AERA_2015_Peck_et_al_sl ides.pdf 